Tatyana Derkach, Doctor of Economic Sciences, Professor, Head of Department of Management, International Humanitarian University (Odesa, Ukraine)

\title{
ANALYSIS OF THE CURRENT TRENDS OF GOLD AND FOREIGN EXCHANGE RESERVES OF THE G20 COUNTRIES
}

\begin{abstract}
During periods of instability, the availability of reserves in the national economy of a country, necessary to overcome crises and repay their negative effects, is of great importance. The economic policy of the G20 countries on the formation of international reserves will give us a general idea of the main trends in this direction. The change in the structure of gold and FX reserves among the group of G20 countries in 2007-2019 is analyzed, the average annual absolute level of gold reserves and their growth have been determined, the amplitude of fluctuations, average deviation and coefficient of variation of gold reserves of the G20 countries have been determined, based on the calculation of the pairwise linear correlation of the gold and foreign exchange dynamics between the G20 countries, the similarities and differences in the implementation of the state policy on international reserves management were determined.
\end{abstract}

Keywords: gold and foreign exchange (international) reserves (gold reserves) of the G20 countries, 19 countries of the Eurozone, rating of the G20 countries in terms of dynamics and variations in gold and $F X$ reserves, pair correlation of changes in international reserves among the $G 20$ countries

\section{Introduction}

The increase of the frequency and scale of global crises are forcing states to create political and economic groups. The close cohesion of countries allows their national economies to stand more confidently and keep up with the challenges of today.

From time immemorial, various states have sought to create and accumulate reserves of precious metals. But to increase resilience to crises at the state level, the accumulation of foreign exchange reserves has been an equally important issue since the 19th century.

Attitudes toward gold and foreign exchange reserves (hereinafter - GFER) have changed with the evolution of the international monetary system, as a result of which central banks around the world have changed the size and composition of the reserve portfolio.

The crisis of 2008, which shook the entire world economy, helped to increase the need 
for foreign exchange reserves for the needs of the state foreign exchange and monetary policy.

Another shock to the world economy was the Covid-19 pandemic in early spring 2020, which further increased the urgency of the formation and use of the country's gold and foreign exchange reserves to overcome the crisis.

The works of many domestic and foreign scientists and practitioners are devoted to the study of the history, role, composition, functions of gold and foreign exchange reserves (international reserves) in the economy, as well as the development of economic policy for the management of gold reserves. Domestic scientists began to study the problem of formation and use of gold and foreign exchange reserves only in the late 1990 years.

History, essence, composition and modern functions of gold and foreign exchange reserves are considered in the works of Narkevich S. [Narkevich S., 2015], Ugolini S. [Ugolini S., 2011, 2012]. In the works of Vlasenko E. Yu. [Vlasenko, E. Yu., 2011], Zolotareva A. [Zolotareva A., 2001], Drobyshevskogo S., Sinelnikova S., Kadochnikova P., Aizenman J. [Aizenman J., 2001], Obstfeld M. [Obstfeld M.,2010] gold and foreign exchange reserves are considered as the basis for the stability of the country's currency. The role of gold in economics and politics is studied in the works of Katasonov V. Yu. [Katasonov V., 2009]. The works of Petrikova E., Petrikova S. [Petrikova E., 2012], Alfaro L. [Alfaro L.,2013], Black S. W. [Black S.,1985], Blackman C. [Blackman C., 1982], Borio C. [Borio C, 2008a, 2008b], Shapiro M. D. [Shapiro M., 1987], Wang G. [Wang G.,2012] are devoted to the issues of theory, methodology and practice of international reserves management.

World trends in the accumulation and use of international gold and foreign exchange reserves are considered in the works of Demchenko M. Yu. [Demchenko M. Yu., 2013], Kozlovsky R. [Kozlovsky R. 2010].

In the works of Narkevich S.,Obstfeld M. [Obstfeld M. 1980] the issues of finding the optimum in the accumulation of gold reserves are considered. In his works Truman E. M. [Truman E., 2006] argues in favor of developing an international standard for the diversification of reserves. In his works, Sachs J. [Sachs J., 1983] made an attempt to consider international politics through the prism of a dynamic macroeconomic model.

Despite the significant achievements of domestic and foreign scientists in studying the accumulation and use of international reserves, many issues remain out of their attention, especially in terms of finding common trends and interdependence of the world's largest economies in crisis and inter-crisis periods.

In today's world, the deepening of the international division of labor and the close integration and cooperation between countries make them very sensitive and dependent on 
each other and on the state of the international economy as a whole.

During periods of instability, the availability of reserves in the national economy of a country, necessary to overcome crises and repay their negative effects, is of great importance.

The economic policies of the G20 countries, which together produce about $85 \%$ of the world's gross national product, where the $2 / 3$ of the world's population live and account for $75 \%$ of world trade, on the formation of international reserves, will give us a general idea of the main trends in this direction.

\subsection{Analysis of the Dynamics of the Accumulation of Gold and Foreign Exchange Reserves}

The purpose of the article is to clarify the essence of the concept of gold and foreign exchange (international) reserves, their components and functional purpose; dynamics and variations in the size of gold and foreign exchange (international) reserves of the G20 countries, as well as in a comparative analysis of the economic policy of these countries on the formation and use of gold and foreign exchange reserves.

Modern scientific literature gives two main interpretations of the concept of gold and foreign exchange (international) reserves:

1) as liquid funds managed by the central bank of the country and used for the purposes of monetary policy to manage the exchange rate and mitigate shocks in foreign trade;

2) as all official (owned by government agencies) financial assets of the country, denominated in foreign currencies.

The following definition of international reserves can be found on the IMF website: "Reserve assets are external assets that are freely available to monetary regulators and are controlled by them in order to meet the needs of financing the balance of payments, interventions in foreign exchange markets to influence exchange rate and for other relevant purposes (such as maintaining confidence in the currency and the economy, as well as as a basis for foreign borrowing)" [8].

The IMF's international reserves in terms of financial instruments include: monetary gold, holdings in the SDR, reserve position in the IMF, cash and foreign currency deposits, securities,

derivative financial instruments (currency-related), other assets (loans, borrowings and etc.), in some cases, the composition of gold and foreign exchange reserves include funds SWF, asset pools and currency swaps between central banks [8].

In Ukraine, international reserves are divided into two parts according to subjectivity:

1) reserves managed by the National Bank of Ukraine,

2) reserves managed by the government. 
Despite this division, in the literature, as a rule, when considering gold and foreign exchange (international) reserves, their total value is considered, without division into parts according to affiliation.

In the modern economy, the main motives of the state to create gold and foreign exchange reserves are the need for reserves for:

1) smoothing of short-term exchange rate fluctuations,

2) smoothing of exchange rate fluctuations, which are stable and long-lasting,

3) lowering the national currency, which will increase the competitiveness of the economy.

Accordingly, there are three functions of foreign exchange reserves, such as [Narkevich S. 2015, p.97]:

1) support for liquidity in the foreign exchange market,

2) counteracting balance of payments shocks,

3) stimulating export-oriented growth.

The main objectives of creating gold and foreign exchange reserves are to guarantee the country's solvency in international settlements and maintain the required level of the national currency exchange rate, as well as maintaining the stability of the country's economy.

Analysis of the formation of international reserves by the G20 countries, we begin with a study of the dynamics of the accumulation of gold and foreign exchange reserves, the calculation of growth rates and growth of GFER (Fig. 1-3, table. 1-3).

The aggregate GFE reserves of the G20 countries changed ambiguously during the study period: they increased in 2007-2013, 2017, 2019, and decreased in 2014-2016 and 2018. Growth of international reserves in 2008-2009 was mainly due to the accumulation of reserves by China, whose share in the G20, ranged from $29.47 \%$ in 2007 to $42.27 \%$ in 2014 , is dominant.

On the graph (Fig. 1) we see that the constructed linear trend differs significantly from the pattern of changes in aggregate gold reserves in the G20 countries. More precisely, the dynamics of change of this parameter is reflected by the polynomial type of the trend line. 


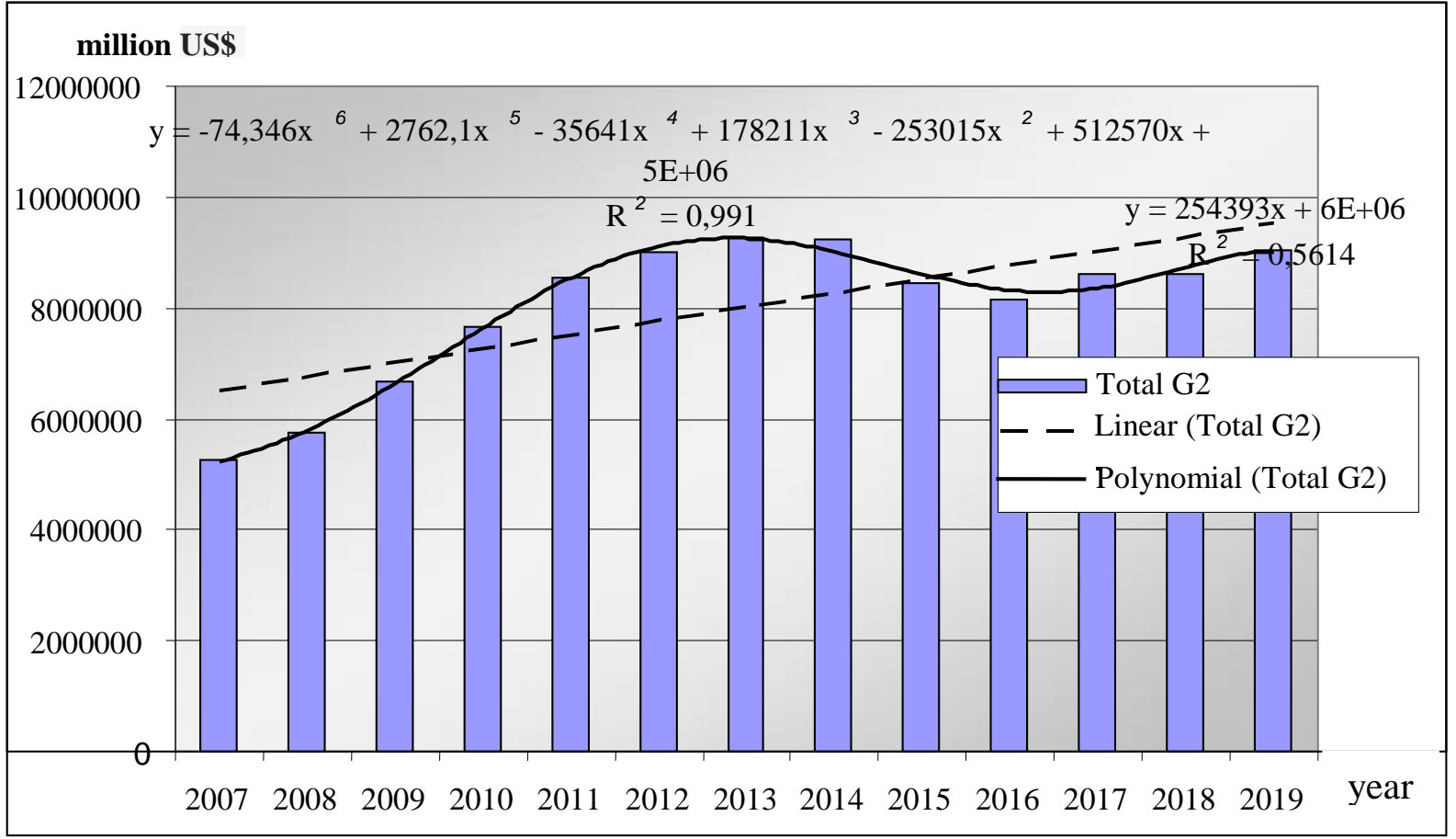

Figure 1. - Dynamics of GFER of the G20 countries for the period 2007-2019.

Source: author's calculations according to the World Bank

During 2007-2019 years China was and remains the leader in the absolute value of gold and foreign exchange reserves among the G20 countries. With a significant gap from it, Japan ranks the second. At the 3rd and 4th steps, respectively, the total gold and foreign exchange reserves of 19 Eurozone countries and the reserves of Saudi Arabia. After the financial crisis of 2008-2009, the international reserves of Russia and the United States are almost at the same level, but their trends for the period under study are different: if in the United States the trend is slowly rising, in Russia it is slowly declining.

However, in 2017 Russia was able to turn the tide and its international reserves exceeded those of the United States. Brazil, South Korea, India and Germany close the top ten.

The territorial concentration of gold and foreign exchange reserves is clearly distinguished: on average, more than $58 \%$ of the total reserves of the G20 countries account for only 3 countries (China, Japan and Russia). It is important to note that these are not the geographical centers where financial speculation leads to currency instability, and where, first of all, a significant stock of currency and gold is needed. 
Table 1

The volume of gold and foreign exchange reserves of the G20 countries in million dollars. USA according to the World Bank (World

Bank Total reserves (includes gold, current US\$)

\begin{tabular}{|c|c|c|c|c|c|c|c|c|c|c|c|c|c|c|}
\hline № & Country & 2007 & 2008 & 2009 & 2010 & 2011 & 2012 & 2013 & 2014 & 2015 & 2016 & 2017 & 2018 & 2019 \\
\hline 1 & Australia & 26908 & 32924 & 41742 & 42268 & 46714 & 49138 & 52837 & 53910 & 45712 & 53556 & 66598 & 53881 & 58755 \\
\hline 2 & Argentina & 46149 & 46385 & 48007 & 52208 & 46266 & 43223 & 30534 & 31411 & 25521 & 38415 & 55314 & 66222 & 45216 \\
\hline 3 & Brazil & 180334 & 193783 & 238539 & 288575 & 352010 & 373161 & 358816 & 363570 & 356465 & 364984 & 373956 & 374710 & 356886 \\
\hline 4 & UK & 77715 & 64786 & 79453 & 98025 & 109734 & 117157 & 118750 & 124487 & 148109 & 134932 & 150858 & 172658 & 173569 \\
\hline 5 & Germany & 135932 & 138564 & 179040 & 215978 & 234104 & 248856 & 198535 & 193485 & 173731 & 184031 & 199983 & 198027 & 224028 \\
\hline 6 & India & 276578 & 257423 & 284683 & 300480 & 298739 & 300426 & 298092 & 325081 & 353319 & 361694 & 412614 & 399167 & 463470 \\
\hline 7 & Indonesia & 56936 & 51641 & 66119 & 96211 & 110137 & 112798 & 99387 & 111863 & 105929 & 116370 & 130215 & 120661 & 129186 \\
\hline 8 & Italy & 94109 & 105649 & 131497 & 158478 & 169872 & 181670 & 145725 & 142756 & 130592 & 135133 & 151120 & 152362 & 175398 \\
\hline 9 & Canada & 41082 & 43872 & 54356 & 57151 & 65819 & 68546 & 71937 & 74700 & 79754 & 82718 & 86678 & 83926 & 85297 \\
\hline 10 & China & 1546365 & 1966037 & 2452899 & 2913712 & 3254674 & 3387513 & 3880368 & 3900039 & 3405253 & 3097658 & 3235682 & 3168216 & 3222895 \\
\hline 11 & Mexico & 87208 & 95300 & 99889 & 120584 & 149208 & 167076 & 180200 & 195682 & 177597 & 177974 & 175470 & 176390 & 183056 \\
\hline 12 & Russia & 478822 & 426279 & 439342 & 479222 & 497410 & 537816 & 509692 & 386216 & 368043 & 377052 & 432731 & 468645 & 555179 \\
\hline 13 & Saudi Arabia & 309287 & 451279 & 420984 & 459313 & 556571 & 673740 & 737796 & 744441 & 626990 & 547267 & 509457 & 509469 & 514963 \\
\hline 14 & USA & 277549 & 294046 & 404099 & 488929 & 537267 & 574268 & 448509 & 434416 & 383728 & 405942 & 451285 & 449907 & 516701 \\
\hline 15 & Turkey & 76496 & 73675 & 74933 & 85959 & 87937 & 119183 & 131054 & 127422 & 110490 & 105946 & 107657 & 92983 & 104152 \\
\hline 16 & France & 115487 & 103306 & 131786 & 165852 & 168490 & 184522 & 145161 & 143977 & 138199 & 145866 & 156322 & 166483 & 189006 \\
\hline 17 & South Africa & 32919 & 34070 & 39603 & 43820 & 48748 & 50688 & 49708 & 49122 & 45887 & 47180 & 50723 & 51642 & 55056 \\
\hline 18 & South Korea & 262533 & 201545 & 270437 & 292143 & 306935 & 327724 & 345694 & 362835 & 366707 & 370154 & 388805 & 403082 & 408819 \\
\hline 19 & Japan & 973297 & 1030763 & 1051655 & 1104564 & 1295839 & 1268086 & 1266851 & 1260680 & 1233098 & 1216519 & 1264141 & 1270467 & 1322443 \\
\hline \multirow[t]{2}{*}{20} & Eurozone $^{1}$ & 497921 & 490950 & 609289 & 728826 & 783886 & 843849 & 690423 & 680905 & 630158 & 669157 & 728302 & 743962 & 831941 \\
\hline & Total G20 & 5248100 & 5754757 & 6676029 & 7651990 & 8547894 & 9014392 & 9270650 & 9226779 & 8462759 & 8167518 & 8620484 & 8605987 & 9027584 \\
\hline
\end{tabular}

${ }^{1}$ Note: For the purposes of this study, the G20 does not represent all EU member states, but only 19 Eurozone countries that have abandoned their national currencies in favor of the euro as the single official currency. 
In the nineteenth century, due to in-depth integration processes and globalization, the dynamics of accumulation of gold and foreign exchange reserves in developed countries, developing countries, as well as in Russia and China is very similar - we can see the coincidence of local highs and lows (Fig. 2).

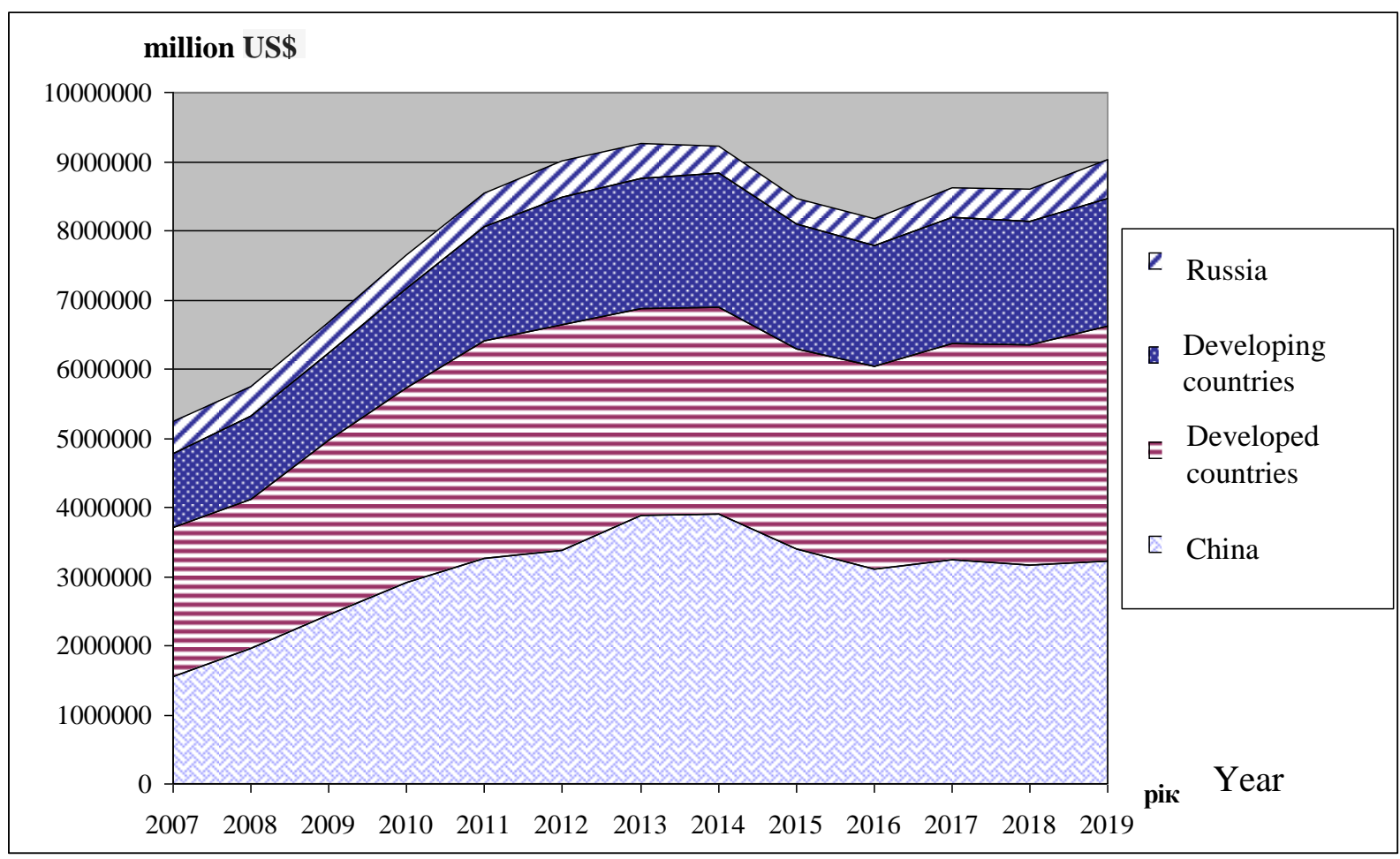

Figure 2 - Dynamics of GFER volumes of the G20 countries

Source: built by the author according to the World Bank

The structure of the group also shows a significant gap in China's leadership (Table 2). The second in the GFER structure of the G20 countries with a significant margin is Japan. The third is the Eurozone. In 2019 Russia, the United States, and Saudi Arabia ranked fourth, fifth, and sixth, respectively. But during 2007-2019 years within these positions they changed places.

Structural shifts in the graph look more stable than the dynamics of absolute volumes (Fig. 3). Collectively, developed countries do not have an advantage in terms of GFER - their total stock is smaller than in other G20 countries, in a ratio of 2: 3 .

It should be noted that the trends in the dynamics of absolute values of GFER do not always coincide with the dynamics of the share of international reserves of the country in the group. The tone is set by China, whose trends in changing these indicators are both positive. But, for example, in Japan, the Eurozone as a whole, Saudi Arabia and the United States, trends are multidirectional: ascending in absolute terms and declining in structure. In Russia, 
both trends are declining, but the dynamics of the absolute indicator shows a slow decline, and the decline in the share in the group structure is faster. 
Table 2

List of G20 countries by volume of gold reserves by group, \%

\begin{tabular}{|c|c|c|c|c|c|c|c|c|c|c|c|c|c|c|c|}
\hline № & Country & 2007 & 2008 & 2009 & 2010 & 2011 & 2012 & 2013 & 2014 & 2015 & 2016 & 2017 & 2018 & 2019 & Rating in 2019 \\
\hline 10 & China & 29,47 & 34,16 & 36,74 & 38,08 & 38,08 & 37,58 & 41,86 & 42,27 & 40,24 & 37,93 & 37,53 & 36,81 & 35,70 & 1 \\
\hline 19 & Japan & 18,55 & 17,91 & 15,75 & 14,43 & 15,16 & 14,07 & 13,67 & 13,66 & 14,57 & 14,89 & 14,66 & 14,76 & 14,65 & 2 \\
\hline 20 & Eurozone & 9,49 & 8,53 & 9,13 & 9,52 & 9,17 & 9,36 & 7,45 & 7,38 & 7,45 & 8,19 & 8,45 & 8,64 & 9,22 & 3 \\
\hline 12 & Russia & 9,12 & 7,41 & 6,58 & 6,26 & 5,82 & 5,97 & 5,50 & 4,19 & 4,35 & 4,62 & 5,02 & 5,45 & 6,15 & 4 \\
\hline 14 & USA & 5,29 & 5,11 & 6,05 & 6,39 & 6,29 & 6,37 & 4,84 & 4,71 & 4,53 & 4,97 & 5,24 & 5,23 & 5,72 & 5 \\
\hline 13 & Saudi Arabia & 5,89 & 7,84 & 6,31 & 6,00 & 6,51 & 7,47 & 7,96 & 8,07 & 7,41 & 6,70 & 5,91 & 5,92 & 5,70 & 6 \\
\hline 6 & India & 5,27 & 4,47 & 4,26 & 3,93 & 3,49 & 3,33 & 3,22 & 3,52 & 4,17 & 4,43 & 4,79 & 4,64 & 5,13 & 7 \\
\hline 18 & South Korea & 5,00 & 3,50 & 4,05 & 3,82 & 3,59 & 3,64 & 3,73 & 3,93 & 4,33 & 4,53 & 4,51 & 4,68 & 4,53 & 8 \\
\hline 3 & Brazil & 3,44 & 3,37 & 3,57 & 3,77 & 4,12 & 4,14 & 3,87 & 3,94 & 4,21 & 4,47 & 4,34 & 4,35 & 3,95 & 9 \\
\hline 5 & Germany & 2,59 & 2,41 & 2,68 & 2,82 & 2,74 & 2,76 & 2,14 & 2,10 & 2,05 & 2,25 & 2,32 & 2,30 & 2,48 & 10 \\
\hline 16 & France & 2,20 & 1,80 & 1,97 & 2,17 & 1,97 & 2,05 & 1,57 & 1,56 & 1,63 & 1,79 & 1,81 & 1,93 & 2,09 & 11 \\
\hline 11 & Mexico & 1,66 & 1,66 & 1,50 & 1,58 & 1,75 & 1,85 & 1,94 & 2,12 & 2,10 & 2,18 & 2,04 & 2,05 & 2,03 & 12 \\
\hline 8 & Italy & 1,79 & 1,84 & 1,97 & 2,07 & 1,99 & 2,02 & 1,57 & 1,55 & 1,54 & 1,65 & 1,75 & 1,77 & 1,94 & 13 \\
\hline 4 & UK & 1,48 & 1,13 & 1,19 & 1,28 & 1,28 & 1,30 & 1,28 & 1,35 & 1,75 & 1,65 & 1,75 & 2,01 & 1,92 & 14 \\
\hline 7 & Indonesia & 1,08 & 0,90 & 0,99 & 1,26 & 1,29 & 1,25 & 1,07 & 1,21 & 1,25 & 1,42 & 1,51 & 1,40 & 1,43 & 15 \\
\hline 15 & Turkey & 1,46 & 1,28 & 1,12 & 1,12 & 1,03 & 1,32 & 1,41 & 1,38 & 1,31 & 1,30 & 1,25 & 1,08 & 1,15 & 16 \\
\hline 9 & Canada & 0,78 & 0,76 & 0,81 & 0,75 & 0,77 & 0,76 & 0,78 & 0,81 & 0,94 & 1,01 & 1,01 & 0,98 & 0,94 & 17 \\
\hline 1 & Australia & 0,51 & 0,57 & 0,63 & 0,55 & 0,55 & 0,55 & 0,57 & 0,58 & 0,54 & 0,66 & 0,77 & 0,63 & 0,65 & 18 \\
\hline 17 & South Africa & 0,63 & 0,59 & 0,59 & 0,57 & 0,57 & 0,56 & 0,54 & 0,53 & 0,54 & 0,58 & 0,59 & 0,60 & 0,61 & 19 \\
\hline \multirow[t]{2}{*}{2} & Argentina & 0,88 & 0,81 & 0,72 & 0,68 & 0,54 & 0,48 & 0,33 & 0,34 & 0,30 & 0,47 & 0,64 & 0,77 & 0,50 & 20 \\
\hline & Total G20 & 100 & 100 & 100 & 100 & 100 & 100 & 100 & 100 & 100 & 100 & 100 & 100 & 100 & \\
\hline
\end{tabular}

Source: calculated by the author according to the World Bank 


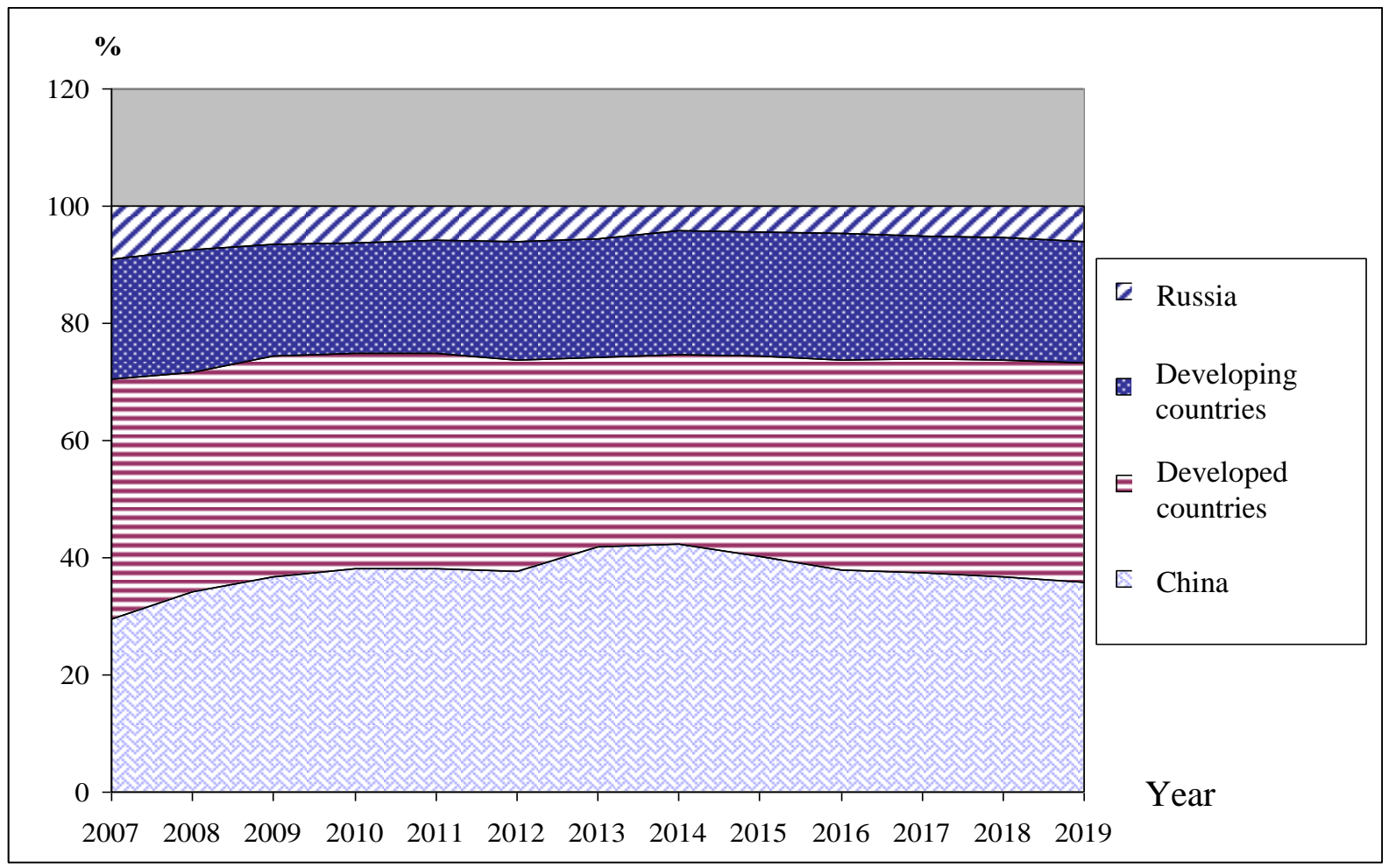

Figure 3 - Dynamics of the GFER structure of the G20 countries

Source: built by the author according to the World Bank

Germany, France, Italy, Turkey, Argentina and South Africa also have divergent trends in these indicators (rising in absolute terms and falling in terms of share in the structure). In Great Britain, Mexico, Indonesia, Canada, Brazil, South Korea, India, and Australia, the trends are equally upward.

As China is the largest holder of international reserves in the G20, changes in the amount of international reserves accumulated by China will significantly affect the change in the total value of international reserves in the group. And, accordingly, the share of other members of the group will be sensitive to changes in China's GFER management policy.

In those countries that accumulate GFER, but at a slower rate than the total group value changes, their share will decrease. And if the country's rate of GFER accumulation exceeds the growth rate of the group amount, the country's share will grow.

During 2007-2019 years Indonesia (6.5\%), Great Britain (6.4\%), and Australia (6.2\%) are in the lead in terms of average annual growth rates of GFER. Mexico and China close the top five with 5.9\% and 5.8\%, respectively. Argentina is an outsider in terms of growth rate $0.16 \%$. Interestingly, Russia was at the bottom of the list, the country with the largest resource base, and Japan that is a small but potentially very powerful Eastern country, which ranks second in absolute terms of international reserves in the G20. 
Table 3

Growth rates of gold reserves of $\mathbf{G 2 0}$ countries

\begin{tabular}{|c|c|c|c|c|c|c|c|c|c|c|c|c|c|c|c|c|}
\hline \multirow{2}{*}{ № } & \multirow{2}{*}{ Country } & \multirow{2}{*}{$\begin{array}{l}2008 / \\
2007\end{array}$} & \multirow{2}{*}{$\begin{array}{l}2009 / \\
2008\end{array}$} & \multirow{2}{*}{$\begin{array}{l}2010 / \\
2009\end{array}$} & \multirow{2}{*}{$\begin{array}{l}2011 / \\
2010\end{array}$} & \multirow{2}{*}{$\begin{array}{l}2012 / \\
2011\end{array}$} & \multirow{2}{*}{$\begin{array}{l}2013 / \\
2012\end{array}$} & \multirow{2}{*}{$\begin{array}{l}2014 / \\
2013\end{array}$} & \multirow{2}{*}{$\begin{array}{l}2015 / \\
2014\end{array}$} & \multirow{2}{*}{$\begin{array}{l}2016 / \\
2015\end{array}$} & \multirow{2}{*}{$\begin{array}{l}2017 / \\
2016\end{array}$} & \multirow{2}{*}{$\begin{array}{l}2018 / \\
2017\end{array}$} & \multirow{2}{*}{$\begin{array}{l}2019 / \\
2018\end{array}$} & \multicolumn{2}{|c|}{ Average annual rate } & \multirow[t]{2}{*}{ Rating } \\
\hline & & & & & & & & & & & & & & increase & growth, $\%$ & \\
\hline 7 & Indonesia & 0,91 & 1,28 & 1,46 & 1,14 & 1,02 & 0,88 & 1,13 & 0,95 & 1,10 & 1,12 & 0,93 & 1,07 & 1,065 & 6,505 & 1 \\
\hline 4 & UK & 0,83 & 1,23 & 1,23 & 1,12 & 1,07 & 1,01 & 1,05 & 1,19 & 0,91 & 1,12 & 1,14 & 1,01 & 1,064 & 6,376 & 2 \\
\hline 1 & Australia & 1,22 & 1,27 & 1,01 & 1,11 & 1,05 & 1,08 & 1,02 & 0,85 & 1,17 & 1,24 & 0,81 & 1,09 & 1,062 & 6,191 & 3 \\
\hline 11 & Mexico & 1,09 & 1,05 & 1,21 & 1,24 & 1,12 & 1,08 & 1,09 & 0,91 & 1,00 & 0,99 & 1,01 & 1,04 & 1,059 & 5,870 & 4 \\
\hline 10 & China & 1,27 & 1,25 & 1,19 & 1,12 & 1,04 & 1,15 & 1,01 & 0,87 & 0,91 & 1,04 & 0,98 & 1,02 & 1,058 & 5,812 & 5 \\
\hline 9 & Canada & 1,07 & 1,24 & 1,05 & 1,15 & 1,04 & 1,05 & 1,04 & 1,07 & 1,04 & 1,05 & 0,97 & 1,02 & 1,058 & 5,781 & 6 \\
\hline 3 & Brazil & 1,07 & 1,23 & 1,21 & 1,22 & 1,06 & 0,96 & 1,01 & 0,98 & 1,02 & 1,02 & 1,00 & 0,95 & 1,054 & 5,391 & 7 \\
\hline 8 & Italy & 1,12 & 1,24 & 1,21 & 1,07 & 1,07 & 0,80 & 0,98 & 0,91 & 1,03 & 1,12 & 1,01 & 1,15 & 1,049 & 4,906 & 8 \\
\hline 14 & USA & 1,06 & 1,37 & 1,21 & 1,10 & 1,07 & 0,78 & 0,97 & 0,88 & 1,06 & 1,11 & 1,00 & 1,15 & 1,049 & 4,897 & 9 \\
\hline 6 & India & 0,93 & 1,11 & 1,06 & 0,99 & 1,01 & 0,99 & 1,09 & 1,09 & 1,02 & 1,14 & 0,97 & 1,16 & 1,041 & 4,051 & 10 \\
\hline 17 & South Africa & 1,03 & 1,16 & 1,11 & 1,11 & 1,04 & 0,98 & 0,99 & 0,93 & 1,03 & 1,08 & 1,02 & 1,07 & 1,040 & 4,035 & 11 \\
\hline 20 & Eurozone & 0,99 & 1,24 & 1,20 & 1,08 & 1,08 & 0,82 & 0,99 & 0,93 & 1,06 & 1,09 & 1,02 & 1,12 & 1,040 & 4,028 & 12 \\
\hline 13 & Saudi Arabia & 1,46 & 0,93 & 1,09 & 1,21 & 1,21 & 1,10 & 1,01 & 0,84 & 0,87 & 0,93 & 1,00 & 1,01 & 1,040 & 4,000 & 13 \\
\hline 5 & Germany & 1,02 & 1,29 & 1,21 & 1,08 & 1,06 & 0,80 & 0,97 & 0,90 & 1,06 & 1,09 & 0,99 & 1,13 & 1,039 & 3,918 & 14 \\
\hline 16 & France & 0,89 & 1,28 & 1,26 & 1,02 & 1,10 & 0,79 & 0,99 & 0,96 & 1,06 & 1,07 & 1,07 & 1,14 & 1,039 & 3,862 & 15 \\
\hline 18 & South Korea & 0,77 & 1,34 & 1,08 & 1,05 & 1,07 & 1,05 & 1,05 & 1,01 & 1,01 & 1,05 & 1,04 & 1,01 & 1,035 & 3,466 & 16 \\
\hline 15 & Turkey & 0,96 & 1,02 & 1,15 & 1,02 & 1,36 & 1,10 & 0,97 & 0,87 & 0,96 & 1,02 & 0,86 & 1,12 & 1,024 & 2,402 & 17 \\
\hline 19 & Japan & 1,06 & 1,02 & 1,05 & 1,17 & 0,98 & 1,00 & 1,00 & 0,98 & 0,99 & 1,04 & 1,01 & 1,04 & 1,024 & 2,386 & 18 \\
\hline 12 & Russia & 0,89 & 1,03 & 1,09 & 1,04 & 1,08 & 0,95 & 0,76 & 0,95 & 1,02 & 1,15 & 1,08 & 1,18 & 1,011 & 1,145 & 19 \\
\hline 2 & Argentina & 1,01 & 1,03 & 1,09 & 0,89 & 0,93 & 0,71 & 1,03 & 0,81 & 1,51 & 1,44 & 1,20 & 0,68 & 0,998 & $-0,157$ & 20 \\
\hline & Total G20 & 1,10 & 1,16 & 1,15 & 1,12 & 1,05 & 1,12 & 1,00 & 0,91 & 0,89 & 1,06 & 1,09 & 1,05 & 1,050 & 5,037 & \\
\hline
\end{tabular}

Source: calculated by the author according to the World Bank 


\subsection{Analysis of Indicators of Variation in the Volume of International Reserves in the G20 Group}

After analyzing the time series, we turn to the analysis of indicators of variation in the volume of international reserves in the G20.

To assess the riskiness of international reserve management policy in the G20, we analyze the magnitude of fluctuations in the absolute value of GFER by country, the average annual level of stocks and the coefficient of variation (Table 4).

To calculate the amplitude of oscillations, we determine the maximum and minimum values of GFER volumes by country, and then find the difference between them. As can be seen from the above calculations, such countries as South Africa, Australia, Argentina, Canada, and Turkey pursue a more stable state policy on the management of international reserves. The largest variation in GFER stocks is observed in China, Saudi Arabia, the Eurozone, Japan and the United States. At the same time, the last five countries are demonstrating a more active foreign economic policy on the world stage.

The average annual level of GFER stocks is highest in China, Japan, the Eurozone and Saudi Arabia, and the lowest is in Turkey, Canada, Australia, South Africa and Argentina.

In order to assess the extent to which GFER provide liquid assets with the balance of payments, further studies should analyze the relationship between average annual GFER stocks and the annual turnover of foreign economic transactions by country.

According to the coefficient of variation, the top five rankings: Japan, Russia, South Africa, the Eurozone and France. These countries pursue a prudent, least risky policy of managing their international reserves. And more chaotic and risky policies in countries such as Britain, Indonesia, Mexico, Argentina and Saudi Arabia. Moreover, if the United Kingdom can afford this without any significant damage to its stability - because, although in 1997 year the final disintegration of the British Empire has ended, the de facto British crown still influences the political and foreign economic processes in the former colonies, which gives the opportunity and advantages in the use of their resources bases in their favor.

In order to find out how similar the G20 countries' international reserves management policy is, we will conduct correlation analyzes and calculate the correlation coefficients between the GFER dynamics of the countries in pairs (Table 5).

The value of the correlation coefficient reflects the strength (density) of the connection. When estimating the bond strength of correlation coefficient, we use the Chaddock scale: the bond density is very weak $[0,0,3)$, weak $[0,30,5)$, medium $[0,50,7)$, high $[0,7,0.9)$, very high $[0.9,1]$. 
Table 4

Indicators of variation in the value of gold reserves of the G20 countries, mln. USA

\begin{tabular}{|c|c|c|c|c|c|c|c|c|c|c|}
\hline № & Country & $\max$ & $\min$ & Amplitude & $\begin{array}{c}\text { Amplitude } \\
\text { rating }\end{array}$ & Mean square deviation & $\begin{array}{c}\text { Mathematical } \\
\text { expectation }\end{array}$ & $\begin{array}{l}\text { Rating by the } \\
\text { first moment }\end{array}$ & $\begin{array}{c}\text { Coefficient } \\
\text { variations, \% }\end{array}$ & $\begin{array}{l}\text { Coefficient of } \\
\text { variation rating }\end{array}$ \\
\hline 1 & Australia & 66598 & 26908 & 39690 & 2 & 10558 & 48072 & 18 & 21,96 & 12 \\
\hline 2 & Argentina & 66222 & 25521 & 40701 & 3 & 10934 & 44221 & 20 & 24,73 & 17 \\
\hline 3 & Brazil & 374710 & 180334 & 194376 & 13 & 71248 & 321215 & 9 & 22,18 & 13 \\
\hline 4 & UK & 173569 & 64786 & 108783 & 10 & 34998 & 120787 & 14 & 28,97 & 20 \\
\hline 5 & Germany & 248856 & 135932 & 112924 & 11 & 33234 & 194177 & 10 & 17,12 & 6 \\
\hline 6 & India & 463470 & 257423 & 206047 & 14 & 61086 & 333213 & 7 & 18,33 & 8 \\
\hline 7 & Indonesia & 130215 & 51641 & 78575 & 6 & 26226 & 100573 & 15 & 26,08 & 19 \\
\hline 8 & Italy & 181670 & 94109 & 87562 & 8 & 25468 & 144182 & 13 & 17,66 & 7 \\
\hline 9 & Canada & 86678 & 41082 & 45596 & 4 & 15604 & 68910 & 17 & 22,64 & 15 \\
\hline 10 & China & 3900039 & 1546365 & 2353675 & 20 & 682033 & 3033178 & 1 & 22,49 & 14 \\
\hline 11 & Mexico & 195682 & 87208 & 108473 & 9 & 38174 & 152741 & 11 & 24,99 & 18 \\
\hline 12 & Russia & 555179 & 368043 & 187137 & 12 & 59741 & 458188 & 5 & 13,04 & 2 \\
\hline 13 & Saudi Arabia & 744441 & 309287 & 435153 & 19 & 126107 & 543197 & 4 & 23,22 & 16 \\
\hline 14 & USA & 574268 & 277549 & 296719 & 16 & 86209 & 435896 & 6 & 19,78 & 11 \\
\hline 15 & Turkey & 131054 & 73675 & 57379 & 5 & 19517 & 99837 & 16 & 19,55 & 10 \\
\hline 16 & France & 189006 & 103306 & 85700 & 7 & 25060 & 150343 & 12 & 16,67 & 5 \\
\hline 17 & South Africa & 55056 & 32919 & 22136 & 1 & 6767 & 46090 & 19 & 14,68 & 3 \\
\hline 18 & South Korea & 408819 & 201545 & 207274 & 15 & 61808 & 331340 & 8 & 18,65 & 9 \\
\hline 19 & Japan & 1322443 & 973297 & 349147 & 17 & 114902 & 1196800 & 2 & 9,60 & 1 \\
\hline \multirow[t]{2}{*}{20} & Eurozone & 843849 & 490950 & 352899 & 18 & 110121 & 686890 & 3 & 16,03 & 4 \\
\hline & Total G20 & 10134450 & 5248100 & 4886350 & & 1603974 & 8344629 & & 19,22 & \\
\hline
\end{tabular}

Source: author's calculations 
Analyzing the results of pairwise correlation, in general in the G20 group it is advisable to identify the following degrees of relationship:

1) such pairs of countries as Australia-Indonesia, Australia-Canada, Australia-South Africa, Brazil-Indonesia, Brazil-Canada, Brazil-China, Brazil-Mexico, Brazil-South Africa, Brazil-Japan, Great Britain-India, Great Britain-Canada, United KingdomSouth Korea, Indonesia-Canada, Indonesia-South Africa, Indonesia-South Korea and Indonesia-Japan, Canada-Mexico, Canada-South Korea, China-Mexico, China-Saudi Arabia, Japan-Mexico, Japan-South Africa, Saudi Arabia-Turkey - pursue a very similar, or interdependent and interdependent policy on the formation of GFER. Germany and France, as the main donors to the EU, of course, mainly determine the policy of forming international reserves throughout the Eurozone, so they have a very strong correlation with each other, as well as with Italy. The density of interaction between the Old and New Worlds shows a very high correlation between pairs of countries: Germany-USA, France-USA and Italy-USA.

2) High sensitivity to GFER management policy is demonstrated by pairs of countries: Australia-Brazil, Australia-UK, Australia-India, Australia-China, Australia-Mexico, Australia-South Korea, Australia-Japan, Australia-Eurozone; Brazil-Great Britain, Brazil-Germany, Brazil-Italy, Brazil-Saudi Arabia, Brazil-USA, Brazil-Turkey, Brazil-France, Brazil-South Korea, Brazil-Eurozone; Great Britain-Indonesia, Great Britain-South Africa, Great Britain-Japan; Germany-Indonesia, Germany-South Africa, Germany-Japan, India-Indonesia, India-Canada, India-South Africa, IndiaSouth Korea, Indonesia-Italy, Indonesia-China, Indonesia-Mexico, Indonesia-USA, Indonesia-France, Indonesia -Eurozone; Italy-South Africa, Italy-Japan; CanadaChina, Canada-South Africa, China-South Africa, Canada-Japan; China-Turkey, China-South Korea, China-Japan; Mexico-Saudi Arabia, Mexico-Turkey, MexicoSouth Africa, Mexico-South Korea; South Africa-USA, South Africa-Turkey, South Africa-France, South Africa-South Korea; South Africa-Eurozone; Japan-Saudi Arabia, Japan-USA, Japan-Turkey, Japan-France, Japan-South Korea; JapanEurozone.

3) in pairs of countries Australia-Argentina, Russia-Australia, Russia-Brazil, RussiaGreat Britain, Russia-India, Russia-Indonesia, Russia-Canada, Russia-China, RussiaMexico, Russia-Saudi Arabia, Russia-Turkey, Russia-South Africa, Russia-South Korea, Russia-Japan, India-Saudi Arabia, Argentina-Brazil, Argentina-Great Britain, Argentina-Germany, Argentina-India, Argentina-Indonesia, Argentina-Italy, 
Argentina - Canada, Argentina - Mexico, Argentina - USA, Argentina - France, Argentina-South Africa, Argentina-South Korea, Argentina-Japan, ArgentinaEurozone - there are no common trends and interdependence in international reserve management policy. About the Russian Federation, which since 2014 is under sanctions in international isolation, it should be said separately. 
Table 5

Pairwise correlation of dynamics of gold reserves of the country G20 for the period 2007-2019

\begin{tabular}{|c|c|c|c|c|c|c|c|c|c|c|c|c|c|c|c|c|c|c|c|c|c|}
\hline № & Country & 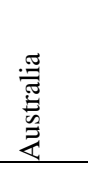 & $\begin{array}{l}\stackrel{\Xi}{\Xi} \\
\stackrel{\Xi}{0} \\
\stackrel{0}{ \pm} \\
\end{array}$ & $\begin{array}{l}\overline{\widetilde{N}} \\
\text { ต }\end{array}$ & 号 & 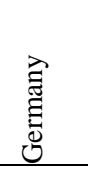 & $\stackrel{\tilde{g}}{\underline{G}}$ & 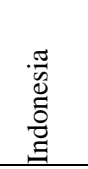 & 䲶 & 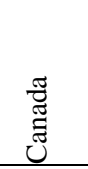 & 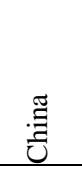 & $\begin{array}{l}\stackrel{0}{x} \\
\stackrel{x}{\Sigma} \\
\end{array}$ & $\begin{array}{l}\frac{\pi}{2} \\
\stackrel{2}{\underline{2}} \\
\end{array}$ & 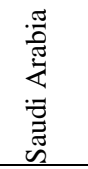 & $\begin{array}{l}\mathbb{2} \\
\text { D2 }\end{array}$ & $\begin{array}{l}\overrightarrow{\vec{d}} \\
\stackrel{\vec{E}}{\Xi}\end{array}$ & 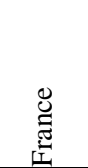 & 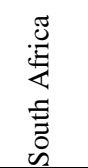 & 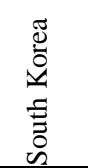 & 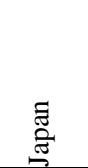 & 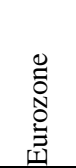 \\
\hline 1 & Australia & 1 & & & & & & & & & & & & & & & & & & & \\
\hline 2 & Argentina & 0,049 & 1 & & & & & & & & & & & & & & & & & & \\
\hline 3 & Brazil & 0,874 & $-0,137$ & 1 & & & & & & & & & & & & & & & & & \\
\hline 4 & UK & 0,815 & 0,077 & 0,827 & 1 & & & & & & & & & & & & & & & & \\
\hline 5 & Germany & 0,595 & 0,110 & 0,720 & 0,455 & 1 & & & & & & & & & & & & & & & \\
\hline 6 & India & 0,775 & 0,218 & 0,624 & 0,920 & 0,333 & 1 & & & & & & & & & & & & & & \\
\hline 7 & Indonesia & 0,907 & 0,038 & 0,949 & 0,894 & 0,723 & 0,789 & 1 & & & & & & & & & & & & & \\
\hline 8 & Italy & 0,662 & 0,148 & 0,750 & 0,548 & 0,987 & 0,448 & 0,771 & 1 & & & & & & & & & & & & \\
\hline 9 & Canada & 0,922 & $-0,057$ & 0,919 & 0,945 & 0,503 & 0,846 & 0,935 & 0,579 & 1 & & & & & & & & & & & \\
\hline 10 & China & 0,778 & $-0,367$ & 0,912 & 0,637 & 0,671 & 0,400 & 0,792 & 0,686 & 0,770 & 1 & & & & & & & & & & \\
\hline 11 & Mexico & 0,856 & $-0,292$ & 0,949 & 0,848 & 0,539 & 0,663 & 0,897 & 0,588 & 0,926 & 0,904 & 1 & & & & & & & & & \\
\hline 12 & Russia & 0,039 & 0,317 & 0,043 & 0,055 & 0,544 & 0,079 & 0,115 & 0,537 & $-0,086$ & 0,012 & $-0,057$ & 1 & & & & & & & & \\
\hline 13 & Saudi Arabia & 0,534 & $-0,596$ & 0,733 & 0,378 & 0,481 & 0,096 & 0,531 & 0,475 & 0,535 & 0,901 & 0,785 & $-0,055$ & 1 & & & & & & & \\
\hline 14 & USA & 0,608 & 0,116 & 0,723 & 0,465 & 0,999 & 0,345 & 0,724 & 0,990 & 0,514 & 0,679 & 0,544 & 0,541 & 0,485 & 1 & & & & & & \\
\hline 15 & Turkey & 0,661 & $-0,557$ & 0,777 & 0,537 & 0,444 & 0,317 & 0,649 & 0,445 & 0,662 & 0,871 & 0,864 & $-0,006$ & 0,908 & 0,442 & 1 & & & & & \\
\hline 16 & France & 0,645 & 0,229 & 0,734 & 0,653 & 0,939 & 0,578 & 0,810 & 0,960 & 0,619 & 0,600 & 0,588 & 0,574 & 0,342 & 0,938 & 0,400 & 1 & & & & \\
\hline 17 & South Africa & 0,900 & $-0,002$ & 0,948 & 0,854 & 0,802 & 0,722 & 0,953 & 0,853 & 0,894 & 0,862 & 0,899 & 0,281 & 0,636 & 0,811 & 0,700 & 0,854 & 1 & & & \\
\hline 18 & South Korea & 0,863 & $-0,024$ & 0,872 & 0,966 & 0,486 & 0,869 & 0,918 & 0,553 & 0,959 & 0,722 & 0,898 & 0,017 & 0,467 & 0,492 & 0,657 & 0,650 & 0,879 & 1 & & \\
\hline 19 & Japan & 0,851 & $-0,134$ & 0,955 & 0,819 & 0,743 & 0,646 & 0,921 & 0,788 & 0,876 & 0,881 & 0,924 & 0,199 & 0,719 & 0,750 & 0,731 & 0,760 & 0,963 & 0,829 & 1 & \\
\hline \multirow[t]{2}{*}{20} & Eurozone & 0,711 & 0,162 & 0,800 & 0,643 & 0,970 & 0,541 & 0,838 & 0,986 & 0,656 & 0,695 & 0,654 & 0,529 & 0,463 & 0,971 & 0,487 & 0,984 & 0,898 & 0,655 & 0,827 & 1 \\
\hline & Total G20 & 0,626 & $-0,448$ & 0,817 & 0,907 & 0,741 & 0,783 & 0,841 & 0,701 & 0,747 & 0,697 & 0,823 & 1 & 0,688 & 0,721 & 0,811 & 0,791 & 0,795 & 0,874 & 0,762 & 0,783 \\
\hline
\end{tabular}


If we calculate the pairwise correlation between the dynamics of GFER in Russia and other countries in the G20 group until 2014, we will see mostly high values of correlation coefficient. This means that no matter how much the Russian authorities assure the world of the ineffectiveness of sanctions, they do. The period of action under the sanctions crossed the interdependence in the development of a common policy for the management of GFER.

4) Other pairs of countries that have not been named have weak and medium sensitivity to GFER management policies to each other - that is, pursue similar GFER management policies situationally, discreetly.

It should also be noted that in the theory of accumulation of gold and foreign exchange reserves should provide increased liquidity and solvency in international trade, as well as economic growth by stimulating exports through the weakening of the national currency. But in practice, the ability to exploit the policy of accumulating reserves to stimulate growth through the development of exports significantly limits the likelihood of appropriate action by other countries or, worse, entire political and economic groups.

\section{Conclusions and Suggestions.}

The main motive of the state to create a GFER is the need for reserves for: 1) smoothing short-term exchange rate fluctuations, 2) smoothing stable and long-term exchange rate fluctuations, 3) curbing the growth of the national currency, which will increase the competitiveness of the economy. In times of crisis, international reserves are of strategic importance for financing critical imports, emergency payments and covering the balance of payments deficit.

During 2007-2019 years the undisputed leader in the accumulation of GFER was and is China - it owns $1 / 3$ of all GFER stocks in the G20. China also has the highest average annual GFER value and the largest amplitude of GFER fluctuations. But in terms of average annual growth, Indonesia became the leader. In terms of average annual growth rates, there is no clear polarity between developed and developing countries. The lowest risk in the management of international reserves is observed in Japan, Russia and South Africa, the highest is in Mexico, Indonesia and the United Kingdom.

The analysis revealed differences between the geographical centers of GFER concentration and the centers of currency instability.

Based on the correlation analysis, pairs of the country in the G20 group were identified, which have a close connection in the development of international reserve management policy and are independent of each other in the formation of the GFER. Indirectly revealed the effect 
of sanctions against Russia since 2014.

Further research should be directed towards the analysis of the GFER composition of individual countries and the assessment of the reliability of reserve assets in conditions of prolonged crisis.

\section{References}

1. Aizenman J., Sun Y. (2012). The financial crisis and sizable international reser-ves depletion: From 'fear of floating' to the 'fear of losing international reser-ves'? International Review of Economics and Finance, Vol. 24, 250-269. https://doi.org/10.1016/j.iref.2012.03.004

2. Alfaro L., Kanczuk F. (2013). Carry trade, reserve accumulation, and exchange-rate regimes. NBER Working Paper, No. 19098.

3. Black S. W. (1985). International money and international monetary arrangements. In: R. W. Jones, P. B. Kenen (eds.). Handbook of International Economics. Vol. 2. Amsterdam: NorthHolland. https://doi.org/10.1016/S1573-4404(85)02013-5

4. Blackman C. (1982). Managing foreign exchange reserves in small developing countries. N. Y.: Group of Thirty.

5. Borio C., Ebbesen J., Galati G., Heath A. (2008a). FX reserve management: Elements of a framework. BIS Papers, No. 38.

6. Borio C., Galati G., Heath A. (2008b). FX reserve management: Trends and challenges. BIS Papers, No. 40.

7. Demchenko, M. Yu. (2013) Hlobalni zolotovaliutni rezervy: suchasnyi stan ta prohnoz Naukovyi visnyk ChDIEU. Seriia 1, Ekonomika. vol. 3 (no. 19), s.108-116 (in Ukrainian) (19). c. 108-116. URL:file:///C:/Users/USER/Desktop/NvChdieu_2013_3_17\%20(1).pdf

8. IMF (2012). Balance of payments and international investment position manual. Washington, DC. URL: www.imf.org. [Accessed 30 September 2020]

9. Katasonov V.Yu. (2009) Zoloto v ekonomike i politike Rossii. Monografiya.: M., “Ankil”, s. 286.

10. Kozlovskyi R. (2010) Svitovi tendentsii akumuliatsii ta vykorystannia mizhnarodnykh zolotovaliutnykh rezerviv Halytskyi ekonomichnyi visnyk. № 2 (27). s. 11-17.

11. Narkevich S. (2015) Zolotovalyutnyie rezervyi: istoriya, opredelenie, sostav i sovremennyie funktsii. Voprosyi ekonomiki. № 4. s. 86-105. https://doi.org/10.32609/0042-8736$\underline{2015-4-86-105}$

12. Obstfeld M. (1980). Macroeconomic policy, exchange-rate dynamics, and optimal asset accumulation. NBER Working Paper, No. 599. https://doi.org/10.3386/w0599 
13. Obstfeld M., Shambaugh J. C., Taylor A. M. (2010). Financial stability, the trilemma, and international reserves. American Economic Journal: Macroeconomics, Vol. 2, No. 2, 57-94. https://doi.org/10.1257/mac.2.2.57

14. Official site of the World Bank. General Reserves URL: https://datacatalog.worldbank.org/total-reserves-includes-gold-current-us

15. Petrykova E.M., Petrykova S.M. (2012) Mezhdunarodnыe rezervы v systeme platezhnoho balansa: teoryia, metodolohyia, praktyka Fynansы y kredyt. Vol. 18, №. 7 (487). URL: https://cyberleninka.ru/article/n/mezhdunarodnye-rezervy-v-sisteme-platezhnogo-balansa-teoriyametodologiya-praktika [Accessed 02 September 2020]

16. Sachs J. (1983). International policy coordination in a dynamic macroeconomic model. NBER Working Paper, No. 1166. https://doi.org/10.3386/w1166

17. Shapiro M. D. (1987). Supply shocks in macroeconomics. NBER Working Paper, No. 2146. https://doi.org/10.3386/w2146

18. Truman E. M., Wong A. (2006). The case for an international reserve diversification standard. Institute for International Economics Working Paper, No. WP 06-2. https://doi.org/10.2139/ssrn.902034

19. Ugolini S. (2011). Foreign exchange reserve management in the 19th century: The National Bank of Belgium in the 1850s. Norges Bank Working Paper, No. 2011/07. https://doi.org/10.2139/ssrn.1935855

20. Ugolini S. (2012). The Bank of England as the world gold market-maker during the classical gold standard era, 1889-1910. Norges Bank Working Paper, No. 2012/15. https://doi.org/10.2139/ssrn.2270721

21. Vlasenko, Ye. Yu. (2011) Zolotovaliutni rezervy yak osnova stabilnosti hroshovoi odynytsi Ukrainy Naukovyi visnyk PUET: Economic Sciences. T. 2, № 6 (51). s. 267-270.

22. Wang G., Zou H. (2012). Foreign asset accumulation, macroeconomic policies and mercantilism. MPRA Paper, No. 34519.

23. Zolotareva A., Drobyishevskiy S., Sinelnikov S., Kadochnikov P. (2001) Perspektivyi sozdaniya stabilizatsionnogo fonda v RF (Nauchnyie trudyi № 27P). M.: Institut ekonomiki perehodnogo peri oda. $76 \mathrm{c}$. 